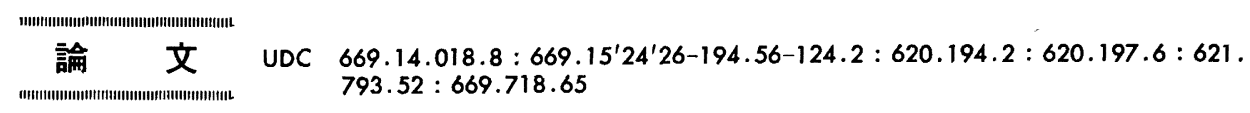

\title{
18-8ステンレス鋼線の応力腐食割れにおよぼす
}

\author{
冷間引抜加工とアルミニウムめつきの影響*
}

\section{Effects of Cold Drawing and Hot Dip Aluminizing on Stress Corrosion Cracking of 18-8 Stainless Steel Wire}

\author{
川端 義則**.西沢 春雄 ${ }^{* *} \cdot$ 西村 強** \\ 生駒 和彦**. 松原 光治** \\ Yoshinori Kawabata, Haruo Nishizawa, Tsuyoshi NishimuRa,
}

Kazuhiko Iкoma, and Mitsuharu Matsubara

\section{Synopsis:}

A study was made of the effects of cold drawing and hot dip aluminizing on stress corrosion cracking (SCC) of 18-8 stainless steel wire. SCC tests were carried out in boiling $42 \% \mathrm{MgCl}_{2}$ solution.

The main results are summarized as follows:

(1) The effect of cold drawing before annealing on the SCC susceptibility was almost negligible.

(2) The effect of cold drawing after annealing on the SCC susceptibility varied with the applied stresses. When applied stress was lower than $10 \mathrm{~kg} / \mathrm{mm}^{2}$, increased susceptibility was observed in a specific range of cold drawing. The maximum susceptibility appeared at $16 \%$ in cold drawing.

(3) The increased susceptibility was accompanied by the formation of $\varepsilon^{\prime}$ martensite, whereas greater cold drawing beyond the susceptible range induced the formation of $\alpha^{\prime}$ martensite. The observed facts suggest the different effect of $\epsilon^{\prime}$ and $\alpha^{\prime}$ martensite on the development of SCC.

(4) When susceptibility was increased by cold drawing, cracks propagated transgranularly to certain depth and then converted to intergranularlyl.

(5) Hot dip aluminizing was beneficial in preventing austenitic stainless steel wire from SGG.

\section{1. 緒言}

オーステナイト系ステンレス鋼の応力腐食割れ（以下 単に SCC) 挙動については実際使用状況下ではともか く，実験室的条件下でも影響を与える因子が複雑で，か つ互に交絡しているため, 現象の統一的把握を困難にし ている、したがつてその防止方法についても完壁なもの は見出し得ないのが実状のようである.ところで, SCC に影響をおよぼす大きな因子の一つとして令間加工があ るが，この影響については HINEs'1)の研究など多くの議 “論がある.2) -7)わが国においても森田8), 前川ら99, 木島10) などによつてその影響が論じられている。森田, 前川, 木島の研究では，供試材として板を用い，加工方法とし て压延あるいは単軸引張によつて加工を加えており, 線 について行なつた研究はわが国では見られない.
周知のことではあるがステンレス鋼線は熱間圧延した 線材を冷間引抜加工して製造される. 压延や単軸引張に よつて材料は加工中に二次元的応力を受けるのに対し て，穴ダイスを用いた冷間引抜加工では三次元的応力を 受けこれにより特殊な瀻維組織を生成する.この加工は 当然 SCC に対しても特殊な影響を与えるものと考えら れる.

一方，オーステナイト系ステンレス鋼の SCC 防止方 法として種々の方法や鋼種が提案されているが，いずれ も完壁とはいえず，また大幅なコスト上昇を招くのが害 状のようである、嵯峨ら"11はアルミニウムめつきはSCC 防止に效果のあることを報告しているが，オーステナイ ト系ステンレス鋼線の場合には連続処理を施すことがで きるので，とくに有効のように思われる.

本研究は以上のような問題意識のもとで，工業的規模

* 昭和 48 年 10 月本会满演大会にて発表 昭和 49 年 7 月 26 日受付 (Received July 26, 1974)

** 神鋼鋼線工業(株) (Shinko Wire Company, 7-2, Doi-cho, Amagasaki, 660) 
Table 1. Chemical composition of alloys investigated. (wt \%)

\begin{tabular}{c|c|c|c|c|c|c|c|c|c}
\hline Alloy & SUS & G & Si & Mn & P & S & Ni & Cr \\
\hline A & 304 & 0.07 & 0.40 & 0.87 & 0.027 & 0.012 & 8.15 & $18 \cdot 83$ \\
\hline B & 304 & 0.07 & 0.43 & 0.96 & 0.021 & 0.016 & 8.15 & $18 \cdot 14$ \\
\hline C & 310 & 0.19 & 1.13 & 1.43 & 0.020 & 0.026 & 19.00 & 23.95 \\
\hline
\end{tabular}

Table 2. Working procedure of specimen.

\begin{tabular}{|c|c|c|c|c|}
\hline \multirow{2}{*}{ Alloy } & \multirow{2}{*}{ Heat treatment and cold drawing } & \multirow{2}{*}{$\begin{array}{l}\text { Specimen } \\
\text { number }\end{array}$} & \multicolumn{2}{|c|}{ Reduction of area** } \\
\hline & & & $\begin{array}{l}\text { Before } \\
\text { annealing }\end{array}$ & $\begin{array}{l}\text { After } \\
\text { annealing }\end{array}$ \\
\hline \multirow{10}{*}{ A } & \multirow{2}{*}{$5 \cdot 05 \phi$ An.*__ $4 \cdot 1 \phi \_3 \cdot 7 \phi \_3 \cdot 3 \phi \_-2 \cdot 9 \phi \square$} & $A-1-S$ & $67 \%$ & \\
\hline & & $\mathrm{A}-1-\mathrm{H}$ & & $67 \%$ \\
\hline & \multirow{2}{*}{$5 \cdot 05 \phi$ An. $-4 \cdot 1 \phi$ An. $-3 \cdot 4 \phi-2 \cdot 9 \phi \quad$ An. $\longrightarrow$} & $A-2-S$ & 50 & \\
\hline & & A $-2-\mathrm{H}$ & & 50 \\
\hline & \multirow{2}{*}{$5 \cdot 05 \phi$ An. $-4 \cdot 1 \phi-3 \cdot 5 \phi$ An. $-2 \cdot 9 \phi \longrightarrow$} & A-3-S & 32 & \\
\hline & & A $-3-H$ & & 32 \\
\hline & \multirow{2}{*}{$5 \cdot 05 \phi$ An. $-4 \cdot 1 \phi-3 \cdot 5 \phi-3 \cdot 15 \phi$ An. $-2 \cdot 9 \phi$ An. $\longrightarrow \rightarrow$} & $A-4-S$ & 16 & \\
\hline & & A $-4-H$ & & 16 \\
\hline & \multirow{2}{*}{$5 \cdot 05 \phi$ An. $-4 \cdot 1 \phi \_3.5 \phi \_3 \cdot 0 \phi$ An. $-2.9 \phi$} & $A-5-S$ & $6 \cdot 5$ & \\
\hline & & $A-5-H$ & & $6 \cdot 5$ \\
\hline \multirow{2}{*}{ B } & $\longrightarrow$ & $\mathrm{B}-\mathrm{N}$ & & \\
\hline & $5 \cdot 05 \phi$ An. $-2 \cdot 2 \phi$ An. $-2 \cdot 0 \phi$ An. $ـ$ Hot dip aluminizing $\rightarrow$ & $\mathrm{B}-\mathrm{Al}$ & & \\
\hline $\mathrm{C}$ & $5 \cdot 05 \phi \mathrm{An} .-3 \cdot 5 \phi \mathrm{An} . \longrightarrow 2 \cdot 2 \phi \mathrm{An} . \longrightarrow 2 \cdot 0 \phi \mathrm{An} . \longrightarrow$ & $\mathrm{C}$ & & \\
\hline
\end{tabular}

* An. : Annealing $1150^{\circ} \mathrm{C} \times 35 \sim 40 \mathrm{sec} / \mathrm{mm}$.-Quench

Drawing Speed : $100 \sim 130 \mathrm{~m} / \mathrm{sec}$

**Reduction of area : $\frac{D_{0}^{2}-D_{1}^{2}}{D_{0}^{2}} \times 100(\%)$

で冷間引抜加工により製造されるオーステナイト采ステ ンレス鋼線の SCC 挙動, ならびにその防止方法として のアルミニウムめつきの効果を明らかにすることを目的 として実施したものである.

\section{2. 供試材および実験方法}

\section{1 化学成分}

実験に用いた供試材の化学成分を Table 1 に示す. オーステナイト系ステンレス鋼の代表的鋼種として 18-8 銅をとりあげた, alloy A は固溶化熱処理前·後の 冷間引抜加工の影響を調ベるため, alloy B はアルミニ ウムメッキの効果を調べる実験, および alloy C は後
者の比較材としてそれぞれ供試材とした。

\section{2 供試材の製作方法}

供試材は熱間压延された $5.5 \mathrm{~mm}$ のステンレス鋼線 材を表面切削し, 固溶化熱処理した後 Table 2 に示す る方法で製作した. 供試材番号末尾 S は $2.9 \mathrm{~mm}$ まで 5 水準の冷間引抜加工を加えた後, 固溶化熱処理したもの （以下 S-Group または焼鈍材と記す場合がある）を 表わし, 同 $\mathrm{H}$ は冷間引抜加工のままのもの（以下 $\mathrm{H}-$ Group または引抜材と記す場合がある）を表わすことと する。また, 冷間引抜加工度は通常減面率と呼んでいる 次式により計算した值を示す. 
減面率 $=\frac{D_{0}^{2}-D_{1}^{2}}{D_{0}^{2}} \times 100(\%)$

ここに $D_{0}$ : 冷間引抜加工前の線径 $\mathrm{mm}$ $D_{1}$ : 冷間引抜加工後の線径 $\mathrm{mm}$

供試材の製作にあたつて，固溶化熱処理には工業用光 輝焼鈍炉，冷間引抜加工には貯線型多頭伸線機之超硬合 金製穴ダイスを用いた。また，アルミニウムめつきはフ ラックス処理を行なつた後, $\mathrm{Si}$ を数％含む溶融アルミ ニウム浴（浴温 $630^{\circ} \mathrm{C}$ ) に連続的に浸漬してめつきし た.

このようにして製作した各伙試忉コイルから試駼片を 所定寸法に連続的に切断し，この中からランダムに取出 して機械的性質の試験および SCC 試験に供した.

\subsection{SCC 試験方法}

SCC 試験はレバー式定荷重応力腐食割れ 試験機を用 いて単軸引張応力下での載荷応力之破断時間の関係を求 め, のちに破断部の組織観察を行なつた.

試験片表面は試験直前にエメリー0/4 研磨・アセトン 脱脂の処理を行なつた.

試験液としては通常オーステナイト系ステンレス鋼の SCC 試験に用いられる $42 \% \mathrm{MgCl}_{2}$ 溶液を用い, 液の 管理は沸点を $142 \pm 2^{\circ} \mathrm{C}$ に制御することによつた。 た, 試験中の溶存酸素濃度の变化, 溶出金属濃度の増加 などによる試験液の劣化については, 試験時間が 100 時 間をこえるごとに液を更新した．この程度の使用時間で あれば液の劣化による破断時間の差はないことを確認し ている.

\section{3. 実 験 結 果}

\section{1 加工にともなう機械的性㑭の変化}

Fig. 1 に alloy A S-Group の機械的性質とオーステ ナイト粒径を示す.

Fig. 2 K alloy A H-Group の機械的性質と透磁率を 示す. 透磁率は固溶化熱処理後の泠閒引抜加工により生 成する加工誘発マルテンサイトの影響を検討するために 測定したもので, 後に考察する.

Table $3 に$ alloy B と Cの機悈的性澌を示す. 溶融 アルミニウムめつきは機械的性質にほとえど影響をおよ ほさない。

\section{2 燎鈍材の SCC 試験結果}

Fig. 3 K alloy A S-Group の試験片に 4 水準の大き さの定值載荷応力を加えて SCC 試験を行なつた場合の 載荷応力上破断時間の関係を示す. 載荷応力 $10 \mathrm{~kg} / \mathrm{mm}^{2}$ 以下の場合には破断時間は非常に大きなバラッキを示す が載荷応力 $15 \cdot 45 \mathrm{~kg} / \mathrm{mm}^{2}$ では破断時間のバラツキはほ
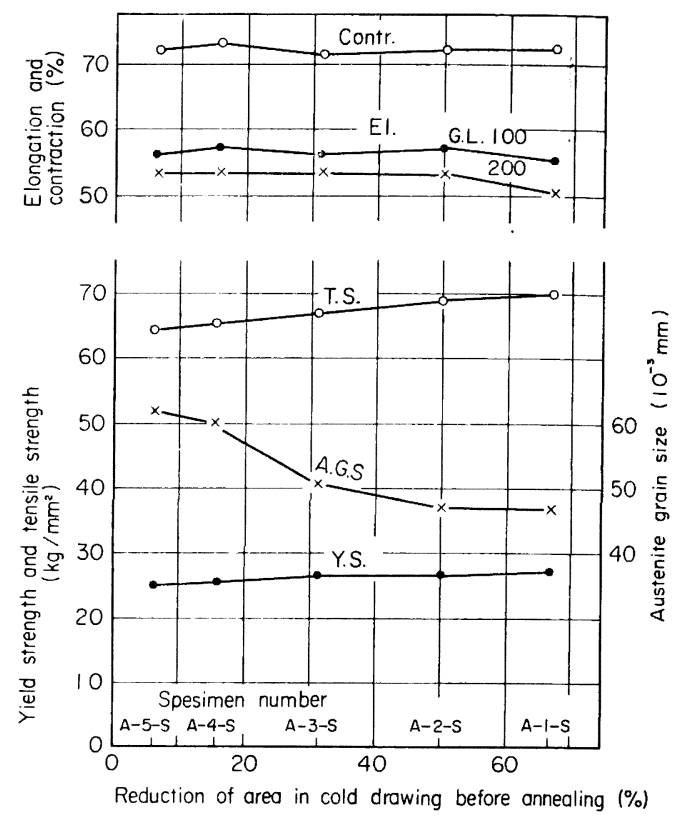

Fig. 1. Mechanical properties of alloy A S-Group.

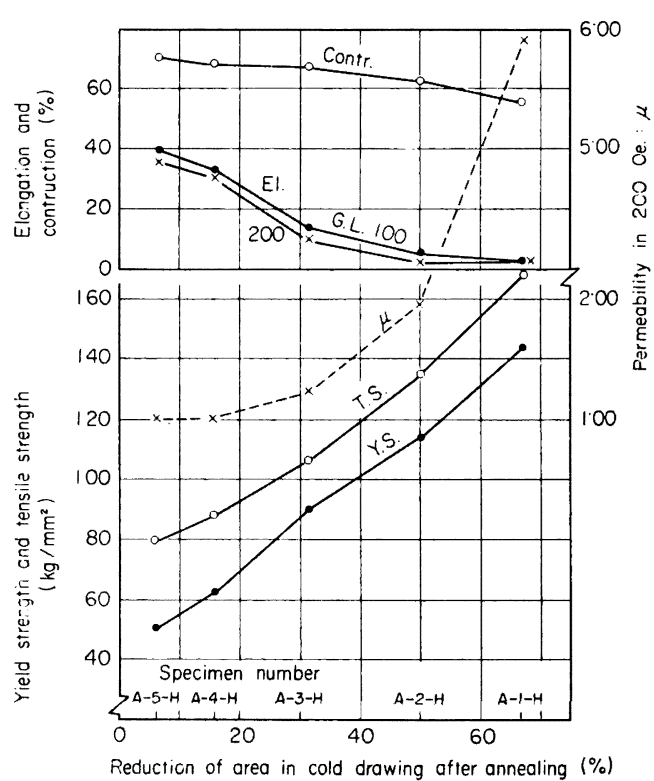

Fig. 2. Mechanical properties and permeability of alloy A H-Group.

とんどない.

破断した試験片を目視および顕微鏡で観察したところ 截荷応力が $10 \mathrm{~kg} / \mathrm{mm}^{2}$ 以下の場合には割れは破断部に のみ集中している.これに対して載荷応力が $15.45 \mathrm{~kg} /$ $\mathrm{mm}^{2}$ の場合には破断部以外にも非常に大きな割れが全 
Tąble 3. Mechanical properties of alloy B and G.

\begin{tabular}{|c|c|c|c|c|c|c|}
\hline \multirow{2}{*}{$\begin{array}{l}\text { Specimen } \\
\text { number }\end{array}$} & \multirow{2}{*}{$\begin{array}{c}\text { Diameter } \\
\mathrm{mm}\end{array}$} & \multirow{2}{*}{$\begin{array}{l}\text { Tensile } \\
\text { strength } \\
\mathrm{kg} / \mathrm{mm}^{2}\end{array}$} & \multicolumn{2}{|c|}{ Elongation \% } & \multirow{2}{*}{$\begin{array}{c}\text { Contraction } \\
\%\end{array}$} & \multirow{2}{*}{$\begin{array}{c}\text { Weight of } \\
\text { aluminizing } \\
\mathrm{gr} / \mathrm{m}^{2}\end{array}$} \\
\hline & & & G.L. $100 \mathrm{~mm}$ & G.L. $200 \mathrm{~mm}$ & & \\
\hline$B-N$ & $1 \cdot 99$ & $77 \cdot 5$ & $46 \cdot 0$ & $44 \cdot 5$ & $69 \cdot 2$ & \\
\hline$B-A l$ & $2 \cdot 05$ & $77 \cdot 2$ & $44 \cdot 0$ & $40 \cdot 5$ & $67 \cdot 3$ & $82 \cdot 3$ \\
\hline C & $2 \cdot 02$ & $79 \cdot 6$ & $37 \cdot 0$ & $37 \cdot 0$ & $51 \cdot 7$ & \\
\hline
\end{tabular}

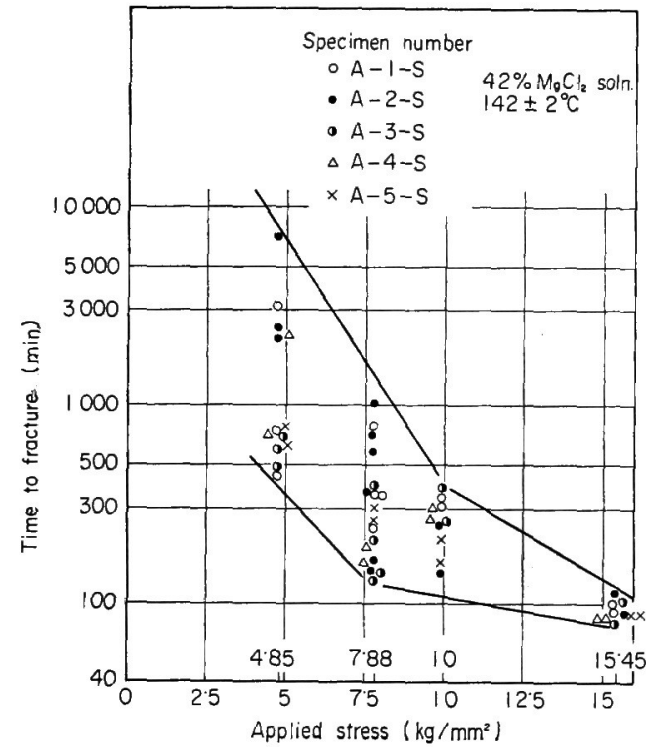

Fig. 3. Effect of cold drawing before annealing on time to fracture of alloy A S-Group.

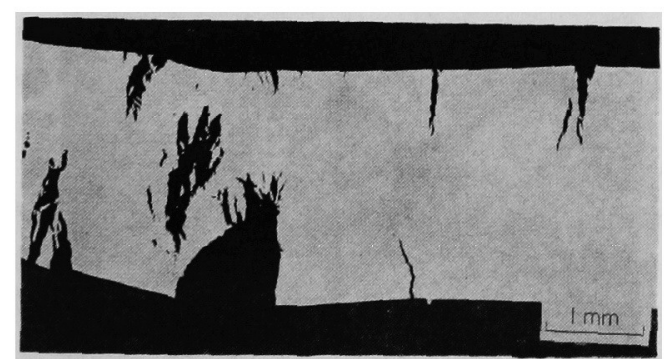

Photo. 1. Gross sectional view of cracking on A1-S in $42 \% \mathrm{MgCl}_{2}$ solution with 15.45 $\mathrm{kg} / \mathrm{mm}^{2}$ stress.

Time to fracture : $1 \cdot 6 \mathrm{hrs}$.

面に発生し，破断に至るまで大きな伸びを生じた．

Photo. 1 に試験片全面にあらわれた大きな割れの様子 を示す. Photo. 2 に割れの顕微鏡組織を示すがオーステ ナイト系ステンレス鋼の SCC に典型的な木の根状に発

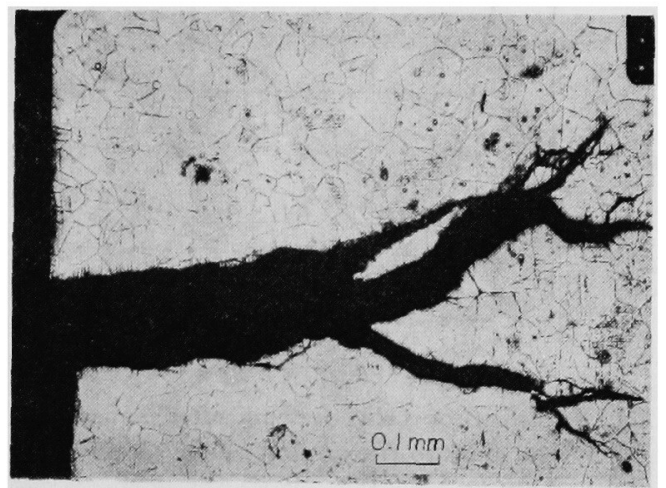

Photo. 2. Typical transgranular fracture on A-4-S in $42 \% \mathrm{MgCl}_{2}$ solution with $15.45 \mathrm{~kg}$ / $\mathrm{mm}^{2}$ stress.

Time to fracture : $1 \cdot 47 \mathrm{hrs}$.

達した粒内割れを示している. 以上の結果は A-1-S〜 A-5-S すべての試験片にみられた.

したがつて, 冷間引抜ののち固溶化熱処理をすれば, この冷間引抜加工度の SCG 挙動におよぼす影響につい ては一定の傾向を見出すことは困難である.

\section{3 引拔材の SCG 試験結果}

Fig. 4 に固溶化熱処理後に 5 水準の冷間引抜加工度を 加えた alloy A H-Group に 3 水準の定値載荷応力㧍よ びおのおのの供試材の降伏強さの $40 \%$ の定率載荷応力 を加えて SCG 試験を行なつた場合の破断時間と冷間引 抜加工度の関係を示している.

載荷応力 $4 \cdot 85,7 \cdot 88 \mathrm{~kg} / \mathrm{mm}^{2}$ の低い定值載荷応力の 場合には冷間引抜加工によつて SCC 感受性が高くなる 加工度の範囲があらわれ，冷間引抜加工度 $16 \%$ で最短 の破断時間を示した. 載荷応力 $15.45 \mathrm{~kg} / \mathrm{mm}^{2}$ の場合 には冷間引抜加工度とともに破断時間は長くなつた，一 方, 定率載荷応力とした場合には載荷応力がそれぞれの 供試材について $20 \mathrm{~kg} / \mathrm{mm}^{2}$ 以上となり，破断時間は焼 鈍材が一番長くなりその後の冷間引抜加工度の影響は明 確にはあらわれなかつた。

割れの形態について焼鈍材の場合と比較すると次のよ うな傾向が明らかとなつた、載荷応力が低い場合には， 


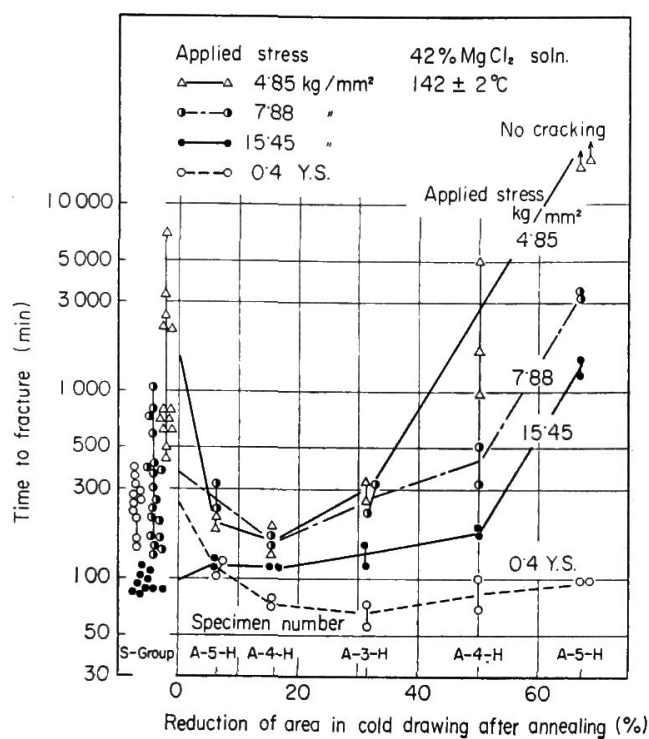

Fig. 4. Effect of cold drawing after annealing on time to fracture of alloy A $\mathrm{H}-\mathrm{Gr}$ oup.

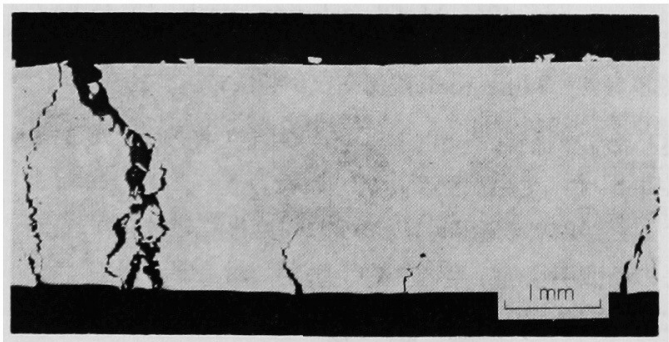

Photo. 3. Cross sectional view of cracking on A$4-\mathrm{H}$ in $42 \% \mathrm{MgCl}_{2}$ solution with 15.45 $\mathrm{kg} / \mathrm{mm}^{2}$ stress.

Time to fracture : $1 \cdot 89 \mathrm{hrs}$.

割れは破断部に集中し数も少ないが載攸応力が高くなる と割れが全面に発生し冷間引抜加工の方向とほぼ直角方 向をなす (Photo. 3) ことは焼鈍材の場合と同じ傾向で ある.しかし，焼鈾材と違つて冷間引抜加工の方向（す なわち引張応力の方向）と同一方向の割れが混在しここ の割れは冷間引抜加工によつて発達した繊維組織に 沿 い，あるいはこれを横切って進えでいる. (Photo. 4)

また，焼鈍材での割れの形態は全て典型的な木の根状 に発達した粒内割れであつた。しかし引抜材にみられる 割れは木の根状に発達してはいても必ずしも粒内割れで はない，表面からある程度粒内割れが進んだ後, 粒界割 れが起こつている.この傾向は最も大きな冷間加工度を 加えた供試材 $\mathrm{A}-1-\mathrm{H}$ では緎維組織の発達のために明膫

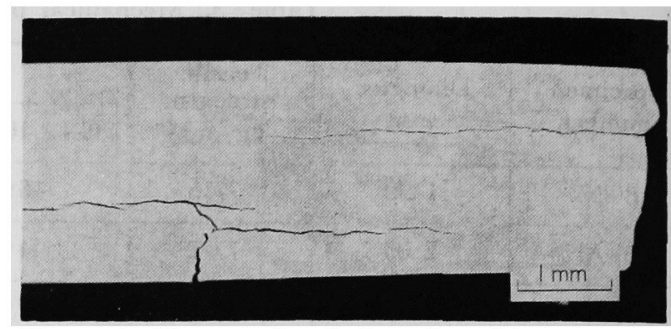

Photo. 4. Cross sectional view of cracking on A-1$\mathrm{H}$ in $42 \% \mathrm{MgCl}_{2}$ solution with $7.88 \mathrm{~kg} /$ $\mathrm{mm}^{2}$ stress.

Time to fracture : $55 \cdot 32 \mathrm{hrs}$.

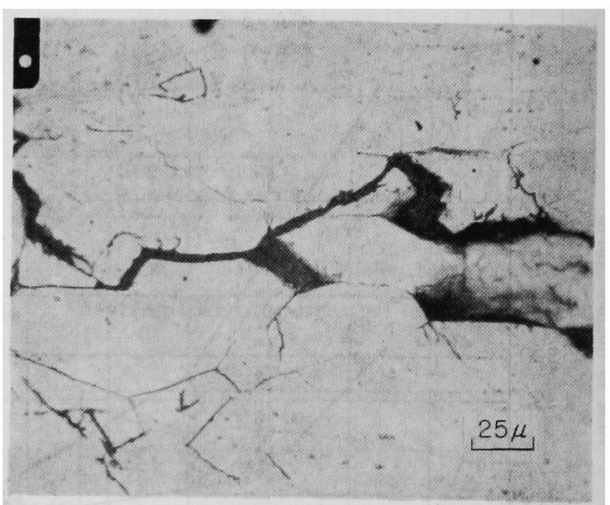

Photo. 5. Intergranular fracture on $\mathrm{A}-2-\mathrm{H}$ in $42 \%$ $\mathrm{MgCl}_{2}$ solution with $45 \cdot 3 \mathrm{~kg} / \mathrm{mm}^{2}$ stress. Timme to fracture : $1 \cdot 69 \mathrm{hrs}$.

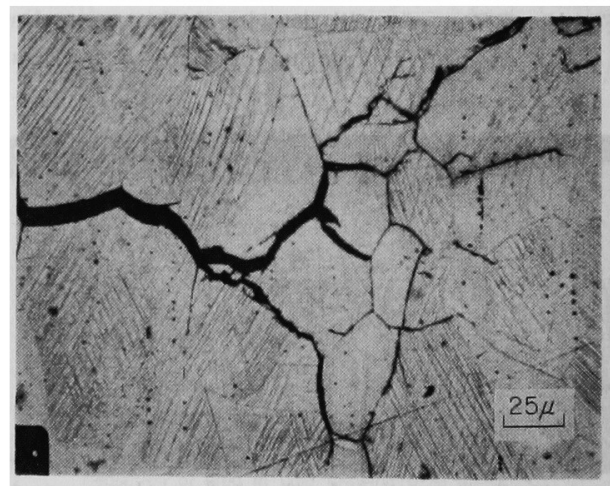

Photo. 6. Intergranular fracture on $\mathrm{A}-4-\mathrm{H}$ in $42 \%$ $\mathrm{MgCl}_{2}$ solution with $15 \cdot 45 \mathrm{~kg} / \mathrm{mm}^{2}$ stress. Time to fracture : $1 \cdot 89 \mathrm{hrs}$.

ではないが，ついで大きな加工を加えた A-2-H でも部 分的に 認められた. (Photo. 5) 小さな冷間引拔加工を 加えたA-4-H，A-5-Hではとくに明瞭に認められた.

(Photo. 6，7) これらの供試材の 加工度は SCC 感受 性が敏感になる範囲である。 
Table 4. Tensile strength of B-Al after SCC tests.

\begin{tabular}{|c|c|c|c|c|c|c|c|c|}
\hline \multirow{3}{*}{$\begin{array}{l}\text { SCG test } \\
\text { condition }\end{array}$} & Solution & \multicolumn{3}{|c|}{$42 \% \mathrm{MgCl}_{2} \cdot 142 \pm 2^{\circ} \mathrm{C}$} & \multicolumn{3}{|c|}{$20 \% \mathrm{NaCl} \cdot 100 \pm 5^{\circ} \mathrm{C}$} & \multirow{3}{*}{$\begin{array}{c}\text { No } \\
\text { SCC } \\
\text { test }\end{array}$} \\
\hline & $\begin{array}{c}\text { Applied stress } \\
\mathrm{kg} / \mathrm{mm}^{2}\end{array}$ & $19 \cdot 1$ & $25 \cdot 4$ & $31 \cdot 8$ & $19 \cdot 1$ & $25 \cdot 4$ & $31 \cdot 8$ & \\
\hline & $\begin{array}{c}\text { Testing time } \\
\mathrm{hr}\end{array}$ & 450 & 340 & 310 & 900 & 900 & 900 & \\
\hline \multicolumn{2}{|c|}{$\begin{array}{l}\text { Tensile strength after SCC } \\
\text { test } \mathrm{kg} / \mathrm{mm}^{2}\end{array}$} & $76 \cdot 0$ & $75 \cdot 5$ & $75 \cdot 5$ & $76 \cdot 0$ & $75 \cdot 8$ & $76 \cdot 5$ & $77 \cdot 2$ \\
\hline \multicolumn{2}{|c|}{$\begin{array}{c}\text { Contraction after SCC test } \\
\%\end{array}$} & $70 \cdot 0$ & $70 \cdot 2$ & $69 \cdot 5$ & $68 \cdot 4$ & $71 \cdot 2$ & $72 \cdot 4$ & $67 \cdot 3$ \\
\hline
\end{tabular}

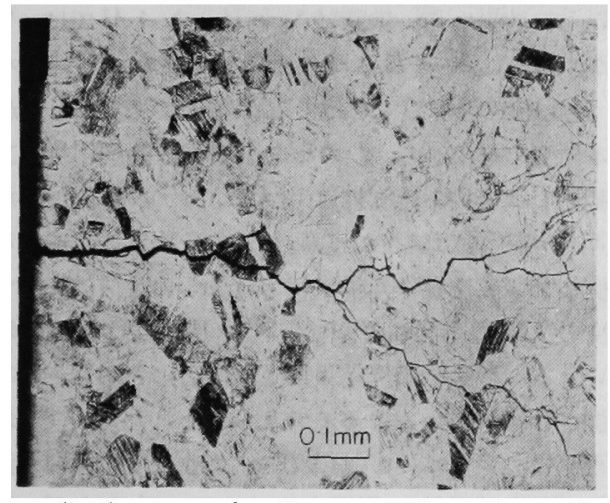

Photo. 7. Intergranular fracture takes place after transgranular SCG develops to a certain degree on $\mathrm{A}-5-\mathrm{H}$ in $42 \% \quad \mathrm{MgCl}_{2}$ solution with $15 \cdot 45 \mathrm{~kg} / \mathrm{mm}^{2}$ stress.

Time to fracture : $2 \cdot 03 \mathrm{hrs}$.

\section{4 アルミニゥムめつき材の SCC 試験結果}

Fig. 5 に沸腾 $42 \% \mathrm{MgCl}_{2}$ 溶液中での $\mathrm{SCC}$ 試験結果 を示す.アルそニウムめつきした供試材 $\mathrm{B}-\mathrm{Al}$ について は $20 \% \mathrm{NaCl}$ 溶液 $\left(100 \pm 5^{\circ} \mathrm{C}\right)$ 中での SCC 試験を追加 したが, $900 \mathrm{hr}$ まで破断は起こらなかつた.これらの SCC 試験後の試験片の引張強さ, 絞り率を Table 4 に 示す.

この表からアルミニウムめつきした供試材 B-Al は42 $\% \mathrm{MgCl}_{2}$ 溶液中お文び $20 \% \mathrm{NaCl}$ 溶液中の $\mathrm{SCC}$ 試験 によつて脆化やへャークラックの発生をおこしていない ことがわかる.

\section{4. 考察}

\subsection{SCC 感受性最大となる冷間加工度}

オーステナイト禾ステンレス鋼の SCC 感受性におよ ほす冷間加工の影響は非常に複雑である. 冷間加工によ つて合金内部に生じた歪, 格子久陌, 変態, 析出などの 金属組織的変化が $\mathrm{SCC}$ 感受性に影響をおよぼすがこれ は鋼種, 加工度, 加工方法によつて変化し, さらに載荷 応力, 腐食環境など SCC 試験条件によつても冷間加工

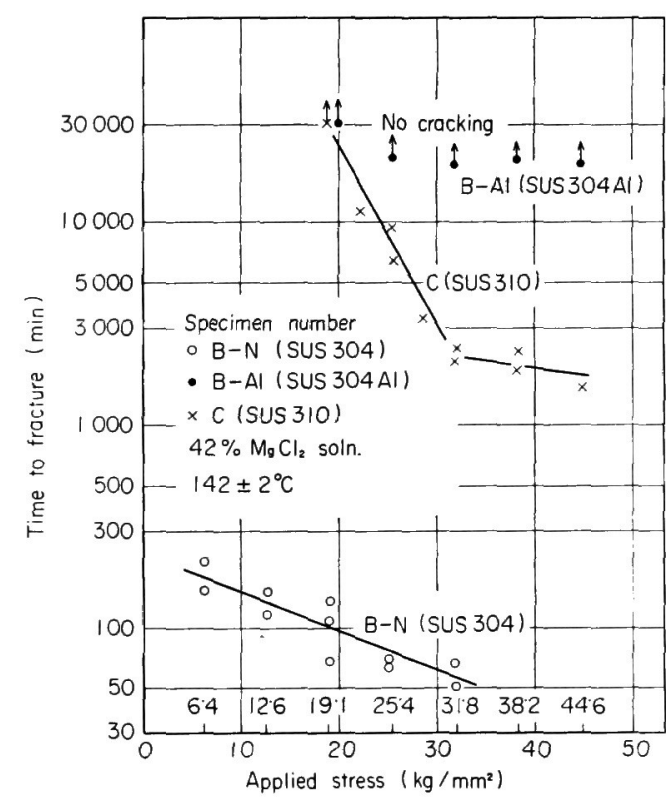

Fig. 5. Effect of aluminizing on time to fracture.

をうけた材料の SCC 感受性は変化する.

HINES 1) -3) は冷間加工度の影響は載荷応力によつて変 化することを示し， $18 \mathrm{Cr}-8 \mathrm{Ni}-\mathrm{Ti}$ 鋼において載荷応 力が余り大きくない場合 $\left(7.8 \mathrm{~kg} / \mathrm{mm}^{2}\right)$ には冷間加工 度 7\%で SCC 感受性が最大となることを見出してい る. HAWKES ら GREELEYら ${ }^{7)}$ は T 302 鋼で同じく 10\%に同様の現象を 報告している。本研究において冷間引抜加工度 $16 \%$ に あらわれた SCC 感受性最大となる現象も上記研究者ら の発見した現象と類似のものと考えられる.

筆者らはオーステナイト系ステンレス鋼線の再結晶過 程について, 固溶化熱処理前にごく小さな冷間引抜加工

（滅面率 $20 \%$ 以下）を加えると固溶化熱処理後の再結 晶粒は大きくなり, 引張強さは低くなることを確認して いる、これはよく知られた現象であるが, 引抜材の SCC 試験において感受性の高くなるのもこの範囲の引抜加工 


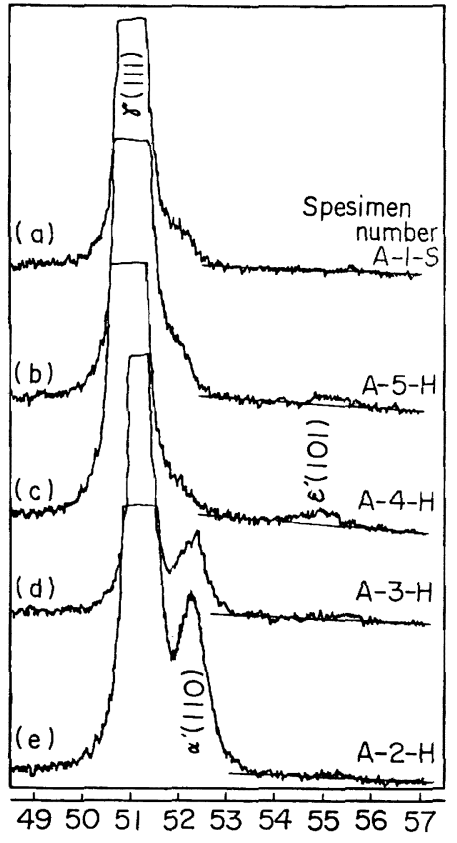

$2 \theta$

(a) as annealed, (b) $6.5 \%$ cold drawn,

(c) $16 \%$ cold drawn, (d) $32 \%$ cold drawn,

(c) $50 \%$ cold drawn

(Target : Co, Voltage $40 \mathrm{kV}$, Current $20 \mathrm{~mA}$, Scanning Speed $1 / 2^{\circ} / \mathrm{min}$ )

Fig. 6. X-ray diffraction pattern for alloy A-1$\mathrm{S}$ and H-Group. $\varepsilon^{\prime}$ and $\alpha^{\prime}$ martensite induced by cold drawing.

度である.さらに Fig. 2 に示したようにこの加工度で はまだ透磁率に変化のあらわれないこと，この範囲で粒 界割れが非常に明瞭にあらわれたことなどは注目すべき 現象である. 以下これらの諸点について考察を進める.

\section{2 加工誘発マルテンサイト}

準安定オーステナィトに Md 点以下の温度で加工を 加えると加工誘発マルテンサイトを生成することは周知 のことである. そしてこのマルテンサイトが腐食されや すいところからこれがオーステナイト系ステンレス鋼の SCC の原因になるという考方が $C$. EDELEANEU らに よつて提出されたが12)，現在では否定されているようで あり ${ }^{13)}$ むしろこのマルテンサイトは SCC 感受性を低 減するとの考え万が多いようである910). 加工誘発マル テンサイトには稠密六方格子をもつ $\varepsilon^{\prime}$ と体心立方格子

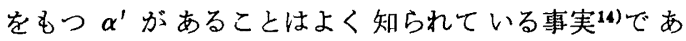
り，したがつて加工誘発マルテンサイトが SCC 感受性 におよぼす影響を評価するさいにも，この両者の役割を 分離して 検討すべきである. そこで $\varepsilon^{\prime}$ および $\alpha^{\prime}$ の有
無を確認するために X 線回折と電子顕微鏡観察を行つ た. 得られた X 線回折図形を Fig. 6 に示寸. 供試材 A-5-H，A-4-H では $\varepsilon^{\prime}(101)$ のピークのみが見られ， A-3-H 以降ではじめて $\alpha^{\prime}(110)$ のピークがあらわれ， $\varepsilon^{\prime}(101)$ のピークは弱くなつている. この結果は Fig. 2 に示した透磁率の変化とも完全に対応する.さらに Photo. 6, 7 の結晶粒内にみられるすじ状組織が $r$ 素地 中に板状に生成した $\varepsilon^{\prime}$ の集合体であることを確認した のが Photo. 8 である.

以上の結果から，供試材 A-5- H， A-4-H では $\varepsilon^{\prime}$ の みが生成し, A-3-H 以降の泠間加工度で $\varepsilon^{\prime}$ は減少し, $\alpha^{\prime}$ の生成が増加していることは明瞭である. したがつ て本研究の結果から $\varepsilon^{\prime}$ のみを生成する冷間引抜加工度 の範囲では SCC 感受性は増大し， $\alpha^{\prime}$ の生成に伴ない SCC の感受性は減少しはじめ， $\alpha^{\prime}$ を大量に生成する冷 間引抜加工度を受けた供試材では $\alpha^{\prime}$ の生成に起因する 強度の大幅な上昇によつて, SCC 感受性は低減される といえる. 従来の研究絬果はこの両者のどちらかのみを 強調されすぎているように考えられる.ただし，これら の現象については， $\varepsilon^{\prime}$ および $\alpha^{\prime}$ の生成そのものが直接

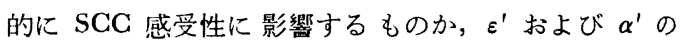
生成は単に副次的な効果を与えるのみであるのかについ てはまだ疑問な点もあり, 今後加工誘発マルテンサイト 変態の 難易度の異なる 鋼種を用いて確認する必要があ る.

\section{3 粒内割れと粒界割れ}

従来，オーステナイト系ステンレス鋼の塩化物による 割れの形態について $\mathrm{MgCl}_{2}$ 溶液中では粒内割れが普通 であり, $\mathrm{NaCl}$ 溶液中では粒界割れが多くなるとされて きた ${ }^{13)}$.この点について嵯峨ら ${ }^{11)}$ は $\mathrm{MgCl}_{2}$ 溶液と $\mathrm{Na}$ $\mathrm{Cl}$ 溶液の沸点における $\mathrm{PH}$ の差から腐食性の強弱に起 因する割れのメカニズムが違つているためと考えてい る.

しかし，岡田ら ${ }^{15)}$ $\mathrm{MgCl}_{2}$ 溶液を用いて，SしS 304 鋼で試験温度が低い場合 $\left(25 \sim 125^{\circ} \mathrm{C}\right)$ 粒内割れがある 程度進んだのちに粒界割れがおこることを見出してい る.

本研究でもすでに述べたように明かに粒界割れが䜑め られた（Photo．5，6，7) 岡田らは焼䤞材を用いてい るのに対して，筆者らの見出した粒界割れの特徴は次の 通りである。

A) SUS 304 鋼で固溶化熱処理後に冷間引抜加工を加 えた供試材に発生した.そして，的マルテンサイトのみ が発生する $20 \%$ 以下の少加工度を加えた供試材で，と くに明瞭な粒界割れがみられた。 


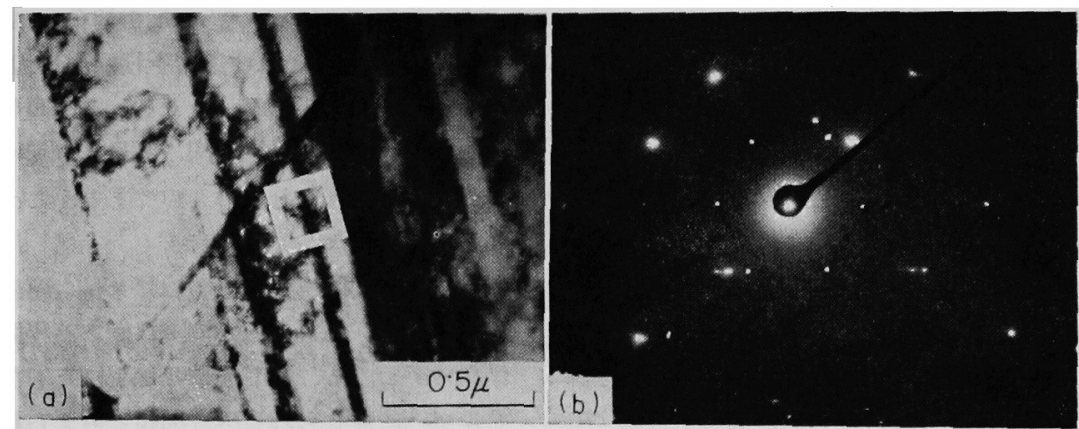

(c)

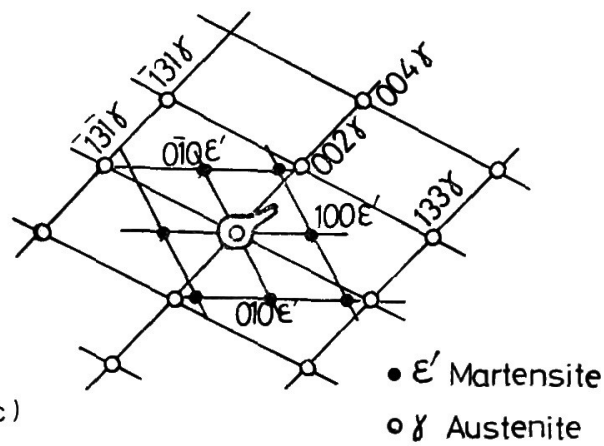

(a) bright field image, (b) diffraction spots, (c) key diagram

Photo. 8. $\varepsilon^{\prime}$ martensite formated in austenite matrix in A-4-H.

B ) $42 \% \mathrm{MgCl}_{2}$ 溶液中で温度は $142 \pm 2{ }^{\circ} \mathrm{C}$ であつた。

C) 粒界割れは粒内割れがある程度進んだ後におこつ た. (Photo. 7)

このような特徵をむつ粒界割れについては，筆者ら以 外には報告がみられないようである.したがつて，その メカニズムについては不明な点が多いが，加工による鋭 敏化と粒界割れについて次のように考えられる.

固溶化熱処理後に冷間引抜加工を加えると, 小さな加 工度で, まず結晶粒が変形をうけて, 加工度とともに個 々の結晶粒の方位が優先方位にそろつてしだいに繊維組 織が形成されてゆくがこの際，まだ繊維組織がほとんど 発達しない小さな加工をうけた供試材では，加工による 昰は粒界に集中し粒界は歪エネルギーの高い状態にあ り，とくに割れやすい状態になる場合があるのではなか ろうか. 岡田らは粒界割れは粒内割れがある程度進えだ 後におこる点をとらえて, 腐食媒の欠泛による腐食性因 子の弱化と粒界割れを結びつけて考察しているが, 本研 究でみられた粒界割れも同様の特徵を有している.した がつて，高い昰エネルギーを貯えた結晶粒界と腐食性因 子との関係について今後更に検討する必要があろう.

また, 加工度と感受性の関係については，正確に説明
すをことは困難であるとしながらも，加工の効果を転位 分布の变化から説明しようとする説もある ${ }^{1617)}$.すなお ち，加工度が小さいと粗大すべりを起こして，転位はプ ラナ構造になり感受性は大きい, 加工度が大きくなると 交差すべりを生じて, 転位はセル構造になるので感受性 はかえつて小さくなる.

しかし，本研究でみられたような加工度の小さい範囲 であらわれた粒界割れの存在，しかも同一試験片で，粒 内割れが途中で粒界割れへ变化する現象などは転位構造 の変化だけでは説明できないように思われる.

いずれにせよ，これらの現象については今後議論を進 めるべき課題であろう.

一方，割れの進行方向は，割れ先端における応力の分 布状態によつて定まり，通常引張応力にほぼ直角であ る.12) 繊維組織が十分発達するような大きな冷間引抜加 工を加えた供試材 A-1-H では引張応力と同一方向に繊 維組織に沿つて伝播している割れがみられるが (Photo. 4 ), 載荷応力が高い場合には繊維組織を切つて進んで いる. したがつて，大きな冷間引抜加工によつて生成し た繊維組織であつても，必ずしも割れ伝播に対して障壁 とはならないようである。 


\section{4 アルミニゥムめつきの効果}

嵯哦ら"1) は純アルミニウムめつきを用いた実験を行な い，SCG 防止に効果のあることを報告しており，これ は主としてめつきされたアルミニウムの溶解時に流れる 腐食電流による陰極防食的作用によるものとしている. また，アルそニウム溶射を儀牲陽極として SCC 防止に 効果があつたという報告も18)ある.

通常, 鋼線のアルミニウムめつきを行なうには純アル ミニウム浴では浴温が高く機械的性質が少化するおそれ があり，更に非常に硬度の高い合金属の成長を抑制する ため, 数 \%の Si を含む浴で浴温をさげてめつきして いる. 本研究でもこの浴を用いた．数％のSi を含む アルミニウムめつきでも SCC 防止の効果は変らず，通 常 SCC 感受性の低いステンレス鋼とされているSUS 310 鋼が SCC 破断する条件でも全く破断せず，脆化も しなかつたしたがつて，工業的見地よりしてアルミニ ウムめつきはオーステナイト采ステンレス鋼の SCGを 防止し，とくに線材の場合には，連続処理が出来るので 低コストでもあり，有効な手段である。

\section{5. 結}

論

18-8 ステンレス鋼線を供試材として $42 \% \mathrm{MgCl}_{2}$ 沸 腾溶液中で SCC 試験老行い，固溶化熱処理前. 後の泠 間引抜加工度とアルミニウムめつきの影響を調べて以下 の結果を得た。

（1）塎固化熱処理前の冷間引抜加工度の SCC 感受 性におよほす影響は，ほぼ無視することが出来る。

（2）固溶化熱处理後の泠間引抜加工度の SCC 感受 性におよぼす影響は載侕応力の大きさによつて变化す る. $10 \mathrm{~kg} / \mathrm{mm}^{2}$ 以上の定值栽倚応力では $\mathrm{SCC}$ 感受性 は加工度により低減される。それ以下の低い定值载荷応 力では，加亡により感受性が高くなる冷間引报加工度の 範囲が存在し，16\% 加工した供試材で最短の破断時間 を示した．定梁載荷応力（40\% Y. S.) とした場合には， 破䉼時問は焼釷材が一番長く, その後の冷間引抜加工度 にはさはど影響されない。

（3）冷間引抜加工によつて SCC の感受性が高くな る加工度の範囲では $\varepsilon^{\prime}$ マルテンテイトのみが生成して おり， $\alpha^{\prime}$ マルテンサイトの生成に伴つて SCC 感受性
は低くなる、したがつて，加工誘発 マルテンサイトの SCC 感受性におよほす影響を検討する際には $\varepsilon^{\prime}$ と $\alpha^{\prime}$ を区別する必要がある，ただし，この現象について，白 および $\alpha^{\prime}$ の生成が直接的に SCC 感受性に影響するも のか，副次的効果をもつものであるかについては明かで はない.

（4）冷間引抜加工によつて SCC 感受性が高くなる 場合には通常みられる粒内割れがある程度進んだ後に粒 界割れがおこる。この現象は加工にともなう粒界の歪工 ネルギーに帰せられるべき閣題と考えられるが詳細につ いては今後の課題である.

（5） Si を少量含むアルミニウムめつきにより 18-8 ステンレス鋼線の SCC をほぼ完全に防止出来た.

\section{交献}

1) J. G. Hines: Physical Metallurgy of Stress Corrosion Fracture, ed. T. N. Rhodin (1959) [Interscience] p. 116

2 ) J.G. Hines and $R$. W. Hugill: Physical Metallurgy of Stress Corrosion Fracture, ed. T.N. Rhodin (1959) [Interscience] p. 193

3 ) J. G. Hines: Corrosion Science, 1 (1961), p. 2

$4)$ H. J. Rocha: Tech. Mitt. Krupp. Forschungsber, 5 (1942), p. 1

$5)$ H. L. Logan and M. J. MaBeE: Mat. Res. Stand. 7 (1967), p. 137

$6)$ H. P. Hawkes, $F . H$. Beck, and $M$. G. FonTANA: Corrosion, 19 (1963), p. $247 \mathrm{t}$.

7 ) $P . J$. Greeley, $V . J$. Russ, $R$. $K$. Saxer, and $J$. R. MAYERS: Corrosion, 21 (1965), p. 321

8 ) 森田: 日本金属学会誌, 25 (1961), p. 667

9 ) 前川, 香川, 中島：日本金属学会誌，27 (1963), p. 548

10）木島：防蝕技術， 17 (1968)，p. 381

11) 戸部, 撯峨, 宮川: 日本金属学会誌, 36 (1972), p. 556

12）下平：日本金属学会報，24（1963）9，A-207

13) 下平：鉄と鋼，55 (1969) 7, p. 604

14）西山：マルテンサイト変態一基礎篇（1971） [丸善]

15）阔田, 細井, 阿部, 山本：日本金属学会誌，37 (1973) 2, p. 197

16）大谷：日本金属学会報, 8 (1969) 10, p. 663

17) 大谷：錟と鋼, 60 (1974) 1, p. 121

18) 森田：ステンレス, 16 (1972) 8, p. 25 